Artikel Penelitian

\title{
Potensi Ekstrak Daun Senduduk (Melastoma malabathricum L.) sebagai Food Additive pada Sosis Daging Sapi
}

Potential Use of Senduduk (Melastoma malabathricum) Leaf Extract as Food Additive on Beef Sausage

Suharyanto ${ }^{1,3_{*}}$, Henny Nuraini ${ }^{1}$, Tuti Suryati ${ }^{1}$, Irma Isnafia Arief $^{1}$, Dondin Sajuthi ${ }^{2}$

${ }^{1}$ Departemen IImu Produksi dan Teknologi Peternakan, Fakultas Peternakan, Institut Pertanian Bogor, Bogor

${ }^{2}$ Departemen Klinik Reproduksi Patologi, Fakultas Kedokteran Hewan, Institut Pertanian Bogor, Bogor

${ }^{3} J u r u s a n$ Peternakan, Fakultas Pertanian, Universitas Bengkulu, Bengkulu

*Korespondensi dengan penulis (suharyanto@unib.ac.id)

Artikel ini dikirim pada tanggal 29 Agustus 2018 dan dinyatakan diterima tanggal 12 Januari 2019. Artikel ini juga dipublikasi secara online melalui https://ejournal2.undip.ac.id/index.php/jatp. Hak cipta dilindungi undang-undang. Dilarang diperbanyak untuk tujuan komersial.

Diproduksi oleh Indonesian Food Technologists® (C2019

\begin{abstract}
Abstrak
Penelitian ini bertujuan untuk menganalisis potensi esktrak daun senduduk (EDS) sebagai food additive pada sosis daging sapi selama penyimpanan dingin. Sebanyak $40 \mathrm{~g}$ bubuk daun senduduk dimaserasi dalam air destilata $(1: 4 ; \mathrm{b} / \mathrm{v})$ selama 24 jam pada suhu kamar, disaring, kemudian di-freeze dry. Empat perlakuan diaplikasikan, yaitu kontrol yang mengandung daging sapi, minyak nabati, susu skim bubuk, tepung tapioka, garam, fosfat, es, dan bumbu-bumbu (kontrol); formula kontrol ditambah dengan ekstrak 0,55\% (EDS), ditambah garam nitrit 0,0011\% (nitrit), dan ditambah keduanya (EDS+nitrit). Hasil penelitian menunjukkan bahwa penambahan EDS dan kombinasinya dengan nitrit menurunkan susut masak sosis. Kandungan nutrisi semua sosis penelitian masuk dalam kategori SNI. Nilai pH sosis menurun akibat pemberian EDS, bukan oleh lamanya penyimpanan. Lama penyimpanan berpengaruh terhadap meningkatnya $a_{w}$ sosis. EDS dan nitrit memberikan efek yang tidak jauh berbeda terhadap daya mengikat air (DMA) yang lebih rendah dibanding kontrol pada hari ke-0. Warna sosis tidak berbeda antar sosis dan lamanya penyimpanan kecuali pada sosis yang diberi nitrit memiliki derajat kemerahan lebih tinggi. Penambahan EDS dapat meningkatkan kandungan senyawa fenolat, aktivitas antioksidan pada sosis, dan menurunkan nilai TBARS serta mereduksi nitrit pada setiap masa penyimpanan. Kombinasi EDS dan nitrit menekan pertumbuhan bakteri hingga penyimpanan hari ke-12. Pemberian EDS saja hanya menekan pertumbuhan bakteri hingga hari ke6. Meskipun demikian secara mikrobiologis, sosis masih masuk kategori SNI kecuali keberadaan Salmonella sp. yang muncul pada hari ke-9. Kesimpulannya, EDS dapat sebagai food additive pada sosis daging sapi.
\end{abstract}

Kata kunci: ekstrak daun senduduk, Melastoma malabathricum, karakteristik sosis.

\begin{abstract}
This study aimed to analyze the potential use of senduduk leaf extracts (SLE) as a food additive in beef sausages during refrigerated storage. A-40 g powder was macerated with distilled water (1:4; w/ $\mathrm{v})$ for $24 \mathrm{~h}$ at room temperature, filtered, and then was freeze-dried. The addition of 0.55\% extract SLE (SLE); 0.0011\% sodium nitrite (nitrite); and both (SLE+nitrite) were used as treatments in sausage making. The results showed the addition of SLE and SLE+nitrite decreased the cooking loss. The nutritional content of all sausages fitted SNI (Indonesia Nasional Standard) category. The decrease in $\mathrm{pH}$ was due to SLE, not by storage. The storage increased $a_{w}$ sausages. SLE and nitrites exerted an equivalent effect on water holding capacity (WHC) compared to control on day 0 . There was no differences on sausage color among treatments and storage except for sausage added with nitrite, which had a higher value in redness. The SLE increased phenolic compounds, antioxidant activity, but decreased the TBARS value and reduced nitrite residue at each storage period. The SLE and nitrite combination declined the bacterial growth until the 12th day of storage, while SLE delayed bacterial growth until day of 6 . Nevertheless, microbiologically, sausage was still included in the SNI category except for the presence of Salmonella sp. on day 9. As conclusion, SLE may provide the potent use for beef sausage processing as food additive.
\end{abstract}

Keywords: senduduk extracts, Melastoma malabathricum, sausage properties.

\section{Pendahuluan}

Peningkatan konsumsi sosis di Indonesia ratarata sebesar $4,46 \%$ pertahun (Anggraeni et al., 2014) merupakan fenomena positif karena meningkatkan asupan protein hewani. Namun, sosis rentan mengalami kerusakan kimiawi dan mikrobilogis, sehingga pembuatannya ditambahkan bahan pengawet seperti butylated hidroxy anisole (BHA), butylated hidroxy toluene $(\mathrm{BHT})$, propyl gallate $(\mathrm{PG})$, nitrat-nitrit, bezoat, sulfit, sorbat, dan lain-lain (Sultana et al., 2014; Carocho et al., 2015) yang memiliki efek negatif terhadap kesehatan manusia (Karakaya et al., 2011; Sultana et al., 2014). Oleh karenanya perlu penggunaan alternatif pengawet alami khususnya senyawa fitokimia (ChavesLópez et al., 2015; Oliveira et al., 2015; Hung et al., 2016). Penggunaan bahan bioaktif alami tersebut dimaksudkan sebagai antioksidan dan antimikroba (Karakaya et al., 2011; Karre et al., 2013; Falowo et al., 2014; Mariem et al., 2014; Radha-Krishnan et al., 2014; Oliveira et al., 2015).

Salah satu sumber bahan fitokimia yang berpotensi untuk dimanfaatkan adalah daun senduduk (Melastoma malabathricum L.). Tumbuhan ini berbentuk perdu dan banyak tumbuh di semak belukar Indonesia. 
Secara tradisional, daun tanaman ini dapat digunakan sebagai obat diare, disentri, infeksi, penutup luka, luccorhea, perawatan pascamelahirkan, dan wasir (Susanti et al., 2007; Susanti et al., 2008). Potensinya sebagai bahan yang dapat dimakan telah dilakukan oleh sebagian masyarakat, yaitu dengan memanfaatkan daunnya untuk menghilangkan rasa pahit pada masakan daun pepaya dan sebagai sayuran pada masakan ikan laut.

Ekstrak daun senduduk memiliki sifat antioksidan, antibakteri (Zakaria et al., 2011; Alnajar et al., 2012; Alwash et al., 2014) dan antifungi (Gholib, 2009). Aktivitas biologisnya sebagai anti-peroksidasi lipida, pegangkut radikal bebas, dan sebagai antiinflamatori (Susanti et al., 2008). Aktivitas antioksidan dan kandungan senyawa fenolat EDS lebih tinggi dibandingkan daun mahkota dewa (Phaleria macrocarpa) dan buah mengkudu (Morinda citrifolia) (Anggraini and Lewandowsky, 2015). Pengujian terhadap tikus dan manusia menunjukkan bahwa daun ini memiliki aktivitas antidiabetik, antihiperlipidema (Balamurugan et al., 2014), antioksidan (Zakaria et al., 2011; Mamat et al., 2013), antiulcer (Balamurugan et al., 2013), dan anti sel kanker (Roslen et al., 2014) serta tidak menimbulkan toksisitas (Alnajar et al., 2012; Alwash et al., 2014).

Berdasarkan hal tersebut, daun senduduk mempunyai potensi menjadi bahan pengawet alami pada produk olahan sosis. Penelitian ini bertujuan untuk menganalisis potensi ekstrak daun senduduk (EDS) sebagai food additive terhadap sifat fisikokimia dan mikrobiologi sosis daging sapi selama penyimpanan dingin. Manfaat yang diperoleh adalah dapat memberikan informasi kepada industri pembuat sosis mengenai penggunaan daun senduduk sebagai food additive.

\section{Materi dan Metode \\ Materi}

Bahan-bahan yang digunakan dalam penelitian ini adalah daun senduduk, air destilata, daging sapi Brahman Cross potongan topside, dan bahan lain untuk pembuatan sosis, diantaranya selongsong sosis, $\mathrm{NaCl}$ fisiologis, buffered peptone water, plate count agar, eosin methylene blue agar, Xylose-Lyxine Deoxycholate Agar, baird parker agar base, tellurite, kuning telur, folinciocalteou, metanol, asam galat, 2,2-diphenyl-1picrylhydrazil, butylated hydroxytoluene, pereaksi $\mathrm{Na}_{2} \mathrm{CO}_{3}$, thiobarbituric acid, trichloroacetic acid, $\mathrm{HCl}$, $\mathrm{NaOH}, \quad$ 1,1,3,3-tetraethoxypropane, $\quad \mathrm{N}$-(1-Naphtyl) ethylenediamine, sulfanilamide, dan bahan-bahan kimia lainnya untuk keperluan analisis. Peralatan yang digunakan selama penelitian ini adalah oven, sieve 35 mesh, rotary evaporator (Heidolph, Antrieb- W-Mikro, Germany), freeze dryer (Snijders Scientific, LY5FME, Netherland), food prosessor, gelas ukur, labu erlenmeyer, labu takar, kertas whatman no 1, cawan petri, sentrifus, spektrofotometer (Agilent, UV-VIS 8453, USA), waterbath (Memmert), pH-meter (Schott Instrument Lab 850, Germany), Aw-meter (Novasina Ms1, Zurich), Chromameter (Konica Minolta, CR 300, USA), lemari es, carver press, dan peralatan lain untuk keperluan analisis.

\section{Metode}

Penelitian meliputi proses ekstraksi daun senduduk, pembuatan sosis, analisa fisik, kimia, dan mikrobiologi sosis berdasarkan waktu penyimpanan dingin $\left(4 \pm 2^{\circ} \mathrm{C}\right)$. Variabel yang diamati meliputi kandungan nutrisi, susut masak, $\mathrm{pH}$, aktivitas air $\left(\mathrm{a}_{\mathrm{w}}\right)$, kadar air, warna, kandungan senyawa fenolat, aktivitas antioksidan, bilangan TBARS, residu nitrit, total plate count, jumlah Escherichia coli, Salmonella sp., dan Staphylococcus aureus. Pengukuran kandungan nutrisi dan susut masak, dilakukan pada hari ke-0. Pengukuran $\mathrm{pH}, \mathrm{a}_{\mathrm{w}}$, kadar air, kandungan senyawa fenolat, aktivitas antioksidan, bilangan TBARS, dan residu nitirit, serta total mikroba dilakukan pada hari ke-0, 3, 6, 9, dan 12 . Penentuan warna dilakukan pada hari ke-0, 6, dan 12.

\section{Ekstraksi daun senduduk}

Daun senduduk (nomor 3 dari pucuk ke pangkal tangkai) dibersihkan dari berbagai kotoran, dikeringanginkan selama 72 jam dan dilanjutkan kering oven suhu $45^{\circ} \mathrm{C}$ selama $4-5$ jam. Kemudian, daun dihaluskan dan diayak menggunakan sieve ukuran 35 mesh. Hasil ayakannya kemudian diekstraksi yang dilakukan dengan mengadopsi penelitian Doughari and Manzara (2008) yang menggunakan pelarut air destilata $1: 10$ (b/v). Sebanyak $40 \mathrm{~g}$ bubuk daun senduduk direndam dalam $400 \mathrm{ml}$ air destilata di dalam labu erlenmeyer $1000 \mathrm{ml}$ dan didiamkan selama 24 jam. Rendaman disaring dengan kertas saring Whatman no 1. Filtrat dievaporasi menggunakan rotary evaporator hingga diperoleh cairan agak kental ekstrak. Cairan ini kemudian di-freeze-dry (suhu $-50^{\circ} \mathrm{C}$ ) hingga diperoleh ekstrak kering. Ekstrak disimpan pada suhu $-20^{\circ} \mathrm{C}$ dalam kondisi ditutup alumunium foil sampai dengan digunakan.

\section{Prosedur pembuatan sosis}

Prinsip utama dalam pembuatan sosis mengadopsi prosedur yang dilakukan oleh Suharyanto et al. (2015) dan Arief et al. (2014a) dengan beberapa modifikasi sesuai dengan perlakuan. Perlakuan pada penelitian ini adalah kontrol, kontrol dengan penambahan EDS 0,55\% (EDS), kontrol dengan penambahan nitrit $0,0011 \%$ (nitrit), dan kontrol dengan penambahan EDS 0,55\% dan nitrit 0,0011\% (EDS+Nitrit). Komposisi bahan pembuatan sosis tertera pada Tabel 1.

\section{Pengukuran susut masak}

Susut masak ditentukan dengan mengadopsi Lee et al. (2008) yang dimodifikasi suhu dan lama pengukusan serta pendinginannya. Adonan dimasukkan ke dalam selongsong ditimbang sebagai berat awal. Sosis kemudian dikukus pada $65{ }^{\circ} \mathrm{C}$ selama 45 menit dan didinginkan pada suhu ruang selama 3 jam. Setelah dingin, sosis ditimbang sebagai berat masak. Susut masak dihitung melalui selisih dari berat awal dan berat 
masak kemudian dibagi dengan berat awal dikalikan 100.

Tabel 1. Formula bahan pembuatan sosis dan penambahan ekstrak daun senduduk

\begin{tabular}{lcccc}
\hline Bahan & \multicolumn{4}{c}{ Perlakuan } \\
\cline { 2 - 5 } & Kontrol & EDS & Nitrit & EDS+nitrit \\
\hline Daging sapi (g) & 500 & 500 & 500 & 500 \\
Minyak nabati (g) & 100 & 100 & 100 & 100 \\
Susu skim (g) & 30 & 30 & 30 & 30 \\
Tepung tapioka & 75 & 75 & 75 & 75 \\
(g) & & & & \\
Es batu (g) & 175 & 175 & 175 & 175 \\
Garam (g) & 15 & 15 & 15 & 15 \\
Bawang putih (g) & 8,75 & 8,75 & 8,75 & 8,75 \\
Merica (g) & 1 & 1 & 1 & 1 \\
Pala (g) & 2,5 & 2,5 & 2,5 & 2,5 \\
STPP (g) & 1,5 & 1,5 & 1,5 & 1,5 \\
NaNO $(g)$ & - & - & 0,01 & 0,01 \\
$(0,0011 \%)^{*}$ & & & & \\
Ekstrak (g) & - & 5 & - & 5 \\
$(0,55 \%)^{*}$ & & 5 &
\end{tabular}

Keterangan: * persen berdasarkan berat total bahan.

\section{Kandungan Nutrisi}

Kandungan nutrisi ditentukan menggunakan metode AOAC (2005). Penentuan kadar air sosis menggunakan metode pengeringan oven pada suhu 105 ${ }^{\circ} \mathrm{C}$. Kadar protein kasar ditentukan metode Kjeldahl, dan pengukuran lemak kasar menggunakan metode soxhletasi. Kadar karbohidrat dihitung secara by difference.

\section{Pengukuran $\mathrm{pH}$}

Nilai $\mathrm{pH}$ sosis diukur menggunakan $\mathrm{pH}$-meter mengikuti prosedur AOAC (2005). Sebanyak 10 gram sosis dihancurkan menggunakan mortar dan kemudian dilarutkan dalam $100 \mathrm{ml}$ air destilata. Larutan ini disaring menggunakan kertas saring dan filtrat diukur $\mathrm{pH}-n y a$.

\section{Pengukuran Nilai $a_{w}$}

Nilai $a_{w}$ sosis diukur menggunakan $a_{w}$-meter yang sebelumnya dilakukan kalibrasi (Lorenzo et al., 2014a). Sosis secukupnya ditumbuk menggunakan mortar kemudian diukur nilai $a_{w}$-nya.

\section{Penentuan Warna}

Warna sosis diukur menggunakan Chromameter yang dinyatakan dalam sistem color hunter. Potongan sampel secukupnya diletakkan di chromameter dan pembacaan warna dinyatakan dalam nilai Hunter $L^{*}, a^{*}$, $b^{*}$. Nilai $L^{*}$ menunjukkan derajat kecerahan dengan nilai 0 adalah hitam dan 100 adalah putih, $a^{*}$ negatif menunjukkan warna kehijauan dan $a^{*}$ positif menunjukkan warna kemerahan, dan $b^{*}$ negatif menunjukkan warna kebiruan dan $b^{*}$ positif menunjukkan warna kekuningan.

\section{Penentuan kandungan senyawa fenolat}

Preparasi sampel dilakukan dengan melarutkan 1 $\mathrm{g}$ sosis lumat ke dalam $5 \mathrm{ml}$ metanol absolut selama 24 jam (Sukisman et al., 2014). Larutan ini kemudian disaring dan filtratnya digunakan untuk pengujian dengan mengikuti prosedur Al-Saeedi and Hossain (2015) dengan sedikit dimodifikasi. Ringkasnya, sebanyak 0,4 ml filtrat direaksikan dengan $3 \mathrm{ml}$ larutan Folin-Ciocalteou 20\%, diamkan selama 5 menit. Campuran ditambahkan $3 \mathrm{ml}$ larutan $\mathrm{Na}_{2} \mathrm{CO}_{3} \quad 10 \%$ kemudian diinkubasi selama 60 menit pada ruang gelap dan suhu kamar. Campuran dibaca absorbansinya dengan menggunakan spektrofotometer pada panjang gelombang $760 \mathrm{~nm}$. Prosedur yang sama dilakukan untuk standar asam galat berbagai konsentrasi (0-16 $\mathrm{mg} / \mathrm{ml}$ ). Kandungan senyawa fenolat dihitung menggunakan persamaan regresi linier hasil ploting absorbansi standar asam galat dan dinyatakan dalam mg ekuivalen asam galat/100 $\mathrm{g}$ bahan kering sosis dengan persamaan $Y=0,0711 x-0,0534$ dan $R^{2}=0,9886$.

\section{Penentuan Aktivitas Antioksidan}

Preparasi sampel dilakukan menggunakan prosedur Sukisman et al. (2014), yaitu melarutkan $1 \mathrm{~g}$ sosis lumat ke dalam $5 \mathrm{ml}$ metanol absolut selama 24 jam. Penentuan aktivitas antioksidan sosis mengikuti prosedur Mahmoudi et al. (2016) dengan sedikit dimodifikasi. Sebanyak 0,2 ml larutan metanolat sampel dicampurkan dengan 1,8 larutan metanolat DPPH $6 \times$ $10^{-5} \mathrm{~mol} / \mathrm{l}$ dan digoyang-goyang selama 20 detik. Setelah itu campuran diinkubasi pada ruang gelap dan suhu kamar selama 60 menit. Campuran diukur absorbansinya menggunakan spektrofotometer pada panjang gelombang $517 \mathrm{~nm}$. Hal yang sama dilakukan terhadap setiap serial pengenceran $(0-4,5 \mathrm{mg} / 100 \mathrm{ml})$ larutan standar BHT. Persen penghambatan DPPH sosis dihitung dengan rumus $\left(\left[A_{\text {kontrol }}-A_{\text {sampel }}\right] / A_{\text {kontrol }}\right) \times$ 100; $A_{\text {kontrol }}$ merupakan nilai absorbansi DPPH tanpa dicampur sampel dan $\mathrm{A}_{\text {sampel }}$ sebagai nilai absorbansi tiap-tiap sampel/standar yang direaksikan dengan DPPH. Kapasitas antioksidan ditentukan dengan menggunakan persamaan regresi linier hasil ploting absorbansi standar BHT dan dinyatakan dalam $\mathrm{mg}$ ekuivalen BHT/100 $\mathrm{g}$ bahan kering sosis dengan persamaan $Y=4,4357 x-3,8005$ dan $R^{2}=0,9919$.

\section{Penentuan Malondialdehida (MDA) \\ Malondialdehida ditentukan menggunakan} TBARS assay mengikuti prosedur Turgut et al. (2016). Sebanyak $5 \mathrm{~g}$ sampel sosis dihancurkan dan dihomogenkan dengan mencampurkan $15 \mathrm{ml}$ air destilata dan disentrifugasi pada $2000 \times$ g selama 15 menit. Kemudian sebanyak $1 \mathrm{ml}$ supernatant ditambahkan dengan $2 \mathrm{ml} 0,25 \mathrm{M} \mathrm{HCl}$ yang mengandung TBA 0,375\% (b/v) dan TCA 15\% (b/v) dan ditambahkan $3 \mathrm{ml} \mathrm{BHT} \mathrm{2 \%}$. Campuran ini di-vortex agar homogen dan selanjutnya diinkubasi pada suhu $100^{\circ} \mathrm{C}$ selama 15 menit. Campuran didinginkan pada suhu ruang kemudian disentrifugasi pada $1000 \times$ g selama 10 menit. Campuran diukur absorbansinya pada panjang gelombang $531 \mathrm{~nm}$ dibandingkan dengan blanko. Larutan standar yang digunakan adalah larutan 1,1,3,3tetraetoksipropana (TEP) 0,002 M yang dibuat secara serial dengan kisaran $2 \times 10^{-6}$ sampai $10 \times 10^{-6}$. Kurva standar dibuat dengan cara memplotkan nilai absorbansi larutan TEP dengan konsentrasi TEP. TBARS diperoleh 
dengan menggunakan persamaan linier hasil ploting kurva standar TEP (dengan persamaan $Y=0,0954 x-$ 0,0959 dan $R^{2}=0,9963$ ) dan dinyatakan dalam mg MDA per $\mathrm{kg}$ bahan kering sosis.

\section{Pengukuran Residu Nitrit}

Residu nitrit ditentukan menggunakan prosedur AOAC (2005). Sebanyak $5 \mathrm{~g}$ sosis dihancurkan, ditambahkan $40 \mathrm{ml}$ air destilata dan dipanaskan hingga mencapai suhu $80^{\circ} \mathrm{C}$. Larutan dipindahkan ke labu volumetrik $500 \mathrm{ml}$ dan ditambahkan air destilata panas hingga volumenya mencapai $300 \mathrm{ml}$. Labu berisi larutan tersebut dimasukkan ke dalam steam bath selama 2 jam dan diaduk-aduk sesekali. Larutan didinginkan pada suhu ruang kemudian ditambahkan air destilata hingga mencapai tanda tera labu. Larutan disaring dengan menggunakan kertas saring.

Filtrat diambil $10 \mathrm{ml}$ dan dimasukkan ke dalam labu volumetrik $50 \mathrm{ml}$. Filtrat ditambah dengan $2,5 \mathrm{ml}$ reagen sulfanolat dan didiamkan selama 5 menit. Setelah itu ditambahkan $2,5 \mathrm{ml}$ reagen $\mathrm{N}$-(1-naftil) etilendiamina $2 \mathrm{HCl}$ (NED) dan dihomogen serta ditepatkan hingga tanda tera. Larutan didiamkan selama 15 menit hingga terbentuk warna merah muda dan kemudian diukur absorbansinya dengan menggunakan spektrofotometer pada panjang gelombang $(\lambda) 540 \mathrm{~nm}$. Hal yang sama juga diukur absorbansinya untuk blanko $45 \mathrm{ml}$ air destilata, 2,5 $\mathrm{ml}$ pelarut sulfanilamida, dan 2.5 $\mathrm{ml}$ pelarut NED. Kurva standar dibuat dari larutan stok $\mathrm{NaNO}_{2}(0,2 ; 0,4 ; 0,6 ; 0,8 \mu \mathrm{g})$ diperlakukan seperti sampel. Kadar nitrit dihitung berdasarkan persamaan regresi linier kurva standar $Y=0,1138 x-0,0101$ dan $R^{2}=0,9953$ yaitu hubungan nilai absorbansi dengan konsentrasi $\mathrm{NaNO}_{2}$ dan dinyatakan dalam mg/kg bahan kering sosis.

\section{Total Mikroba}

Penentuan total mikroba dilakukan dengan mengacu pada Tiwari et al. (2009) dan Arief et al. (2014b). Secara aseptis di dalam laminar, sebanyak 25 $\mathrm{g}$ sampel sosis dihancurkan hingga halus dan dilarutkan hingga homogen ke dalam $225 \mathrm{ml}$ media Buffered Peptone Water (BPW) sebagai pengenceran awal dan dibuat serial pengenceran $10^{-1}, 10^{-2}$, dan $10^{-3}$. Setiap seri pengenceran diambil $1 \mathrm{ml}$ untuk dituangkan ke dalam cawan petri steril yang berbeda kemudian dituangkan media Plate Count Agar (PCA) sebanyak 15-20 ml untuk menentukan total bakteri. Pengenceran $10^{-1}$ dan $10^{-2}$ masing-masing sebanyak $1 \mathrm{ml}$ diinokulasikan ke dalam cawan petri steril yang berbeda dan dituang media Eosin Methylene Blue Agar (EMBA) steril sebanyak 15-20 ml untuk menentukan jumlah $E$. coli. Suspensi pengenceran $10^{-1}$ dan $10^{-2}$ masing-masing diambil $100 \mu \mathrm{l}$ dan diinokulasikan ke dalam cawan petri steril yang berbeda dan dituang media Baird Parker Agar (BPA) steril sebanyak 15-20 ml untuk menentukan jumlah $S$. aureus. Penentuan jumlah Salmonella sp. adalah dengan menginokulasikan $1 \mathrm{ml}$ suspensi dari setiap pengenceran $10^{-1}$ dan $10^{-2}$ ke dalam cawan petri steril dan kemudian dituang Xylose-Lyxine Deoxycholate Agar (XLDA) sebanyak $15-20 \mathrm{ml}$. Setelah semua media memadat, diinkubasi pada suhu $37^{\circ} \mathrm{C}$ selama $24-48$ jam. Setelah itu dihitung jumlah koloninya.

\section{Analisis Statistik}

Percobaan ini menggunakan Rancangan Acak Kelompok Lengkap dua faktor, yaitu pemberian ekstrak daun senduduk dan lama penyimpanan dengan tiga kali ulangan sebagai kelompok. Data yang diperoleh dianalisis dengan menggunakan general linear models pada software SAS versi 9.4 dan uji lanjut Tukey HSD dengan tingkat kepercayaan 95\%. Data mikrobiologi dianalisis secara deskriptif.

\section{Hasil dan Pembahasan}

\section{Kandungan Nutrisi}

Penambahan EDS memberikan efek pada kadar air dan protein yang lebih rendah dan kadar karbohidrat yang lebih tinggi $(P<0,05)$ dibandingkan dengan kontrol meskipun tidak berbeda dengan sosis nitrit dan EDS+nitrit (Tabel 2). Lebih tingginya kandungan karbohidrat pada sosis EDS dan EDS+nitrit diduga karena EDS mengandung senyawa-senyawa nonmetabolit sekunder. Hal ini karena ekstraksi yang dilakukan menggunakan pelarut air menyebabkan bahan non metabolit sekunder seperti karbohidrat, polisakarida, dan asam-asam organik ikut terekstraksi (Chirinos et al., 2007; Chen et al., 2016). Kadar abu sosis tidak berbeda pada semua formula sosis. Kandungan nutrisi semua sosis masih memenuhi standar SNI. Sosis yang diberi ekstrak mengandung kadar abu lebih tinggi dari SNI, maksimal 3\% (BSN, 2015), yaitu 3,13\% dan $3,07 \%$ masing-masing untuk sosis EDS dan sosis EDS+nitrit, meskipun secara statistik tidak berbeda nyata dengan sosis kontrol dan sosis nitrit.

\section{Susut Masak, pH, a $\mathrm{a}_{\mathrm{w}}$, Kadar Air dan Daya Mengikat Air} Penambahan EDS menunjukkan persentase susut masak sosis yang lebih rendah $(P<0,05)$ daripada sosis tanpa EDS, meskipun sosis kontrol dan EDS secara statistik tidak menunjukkan perbedaan yang nyata (Tabel 3). Kisaran susut masak sosis penelitian ini adalah 5,47-6,89\% yang diduga dipengaruhi oleh partikel-partikel ekstrak yang banyak mengandung bahan nonmetabolit sekunder (Chirinos et al., 2007;

Tabel 2. Kandungan nutrisi sosis daging sapi (diukur dari sosis hari ke-0) dalam satuan \%

\begin{tabular}{lccccc}
\hline Sosis & Kadar Air & Abu & Lemak & Protein & Karbohidrat \\
\hline Kontrol & $62,70 \pm 0.15^{\mathrm{a}}$ & $2,99 \pm 0,08^{\mathrm{a}}$ & $10,41 \pm 0,17^{\mathrm{b}}$ & $15,34 \pm 0,23^{\mathrm{a}}$ & $8,57 \pm 0,18^{\mathrm{b}}$ \\
EDS & $61,88 \pm 0,59^{\mathrm{b}}$ & $3,13 \pm 0,09^{\mathrm{a}}$ & $10,61 \pm 0,33^{\mathrm{b}}$ & $14,20 \pm 0,25^{\mathrm{b}}$ & $10,17 \pm 0,51^{\mathrm{a}}$ \\
Nitrit & $62,54 \pm 0,06^{\mathrm{ab}}$ & $2,95 \pm 0,06^{\mathrm{a}}$ & $11,59 \pm 0,21^{\mathrm{a}}$ & $15,50 \pm 0,13^{\mathrm{a}}$ & $7,42 \pm 0,41^{\mathrm{b}}$ \\
EDS+nitrit & $62,05 \pm 0,02^{\mathrm{ab}}$ & $3,07 \pm 0,03^{\mathrm{a}}$ & $12,24 \pm 0,13^{\mathrm{a}}$ & $15,25 \pm 0,44^{\mathrm{a}}$ & $7,39 \pm 0,52^{\mathrm{b}}$ \\
\hline
\end{tabular}

Keterangan: superskrip yang berbeda pada kolom yang sama menunjukkan berbeda nyata $(P<0,05)$ 
Chen et al., 2016) sehingga dapat mempertahankan air dan lemak pada sosis.

Tabel 3. Susut masak sosis daging sapi (\%)

\begin{tabular}{lc}
\hline Sosis & Susut Masak \\
\hline Kontrol & $6,27 \pm 0,25^{\mathrm{ab}}$ \\
EDS & $5,61 \pm 0,04^{\mathrm{bc}}$ \\
Nitrit & $6,89 \pm 0,50^{\mathrm{a}}$ \\
EDS+nitrit & $5,47 \pm 0,13^{\mathrm{c}}$ \\
\hline
\end{tabular}

Keterangan: superskrip yang berbeda menunjukkan berbeda nyata $(\mathrm{P}<0,05)$

Nilai $\mathrm{pH}$ sosis tidak dipengaruhi oleh interaksi formula sosis dan waktu penyimpanan (Tabel 4). Rataan nilai $\mathrm{pH}$ sosis berkisar $5,82-6,08$. Nilai $\mathrm{pH}$ sosis hingga hari ke-3 tidak mengalami perubahan, tetapi cenderung meningkat pada hari ke- 6 dan stabil hingga hari ke-12 penyimpanan. Tidak berubahnya $\mathrm{pH}$ selama penyimanan kemungkinan karena rendahnya aktivitas mikroba pada suatu produk. Ibrahim et al. (2010) menyebutkan bahwa perubahan $\mathrm{pH}$ produk berkaitan dengan aktivitas mikroba. Peningkatan $\mathrm{pH}$ merupakan akibat proses degradasi protein dalam menghasilkan asam amino dan ammonia dan bila $\mathrm{pH}$ menurun adalah disebabkan karena adanya pemecahan karbohidrat dalam aktivitasnya. Sosis yang diberi ekstrak memiliki nilai $\mathrm{pH}$ lebih rendah dibanding sosis kontrol dan nitrit. Hal ini karena adanya peningkatan kadar senyawasenyawa fenolat yang terkandung pada sosis melalui penambahan EDS (Fernandes et al., 2018; Wang et al., 2015). Berdasarkan penelitian sebelumnya, daun senduduk mengandung senyawa-senyawa fenolat (Susanti et al., 2008; Wong et al., 2012; Anggraini and Lewandowsky, 2015). Hal ini sejalan dengan penelitianpenelitian lain bahwa penambahan ekstrak tumbuhan menurunkan nilai pH suatu produk (Devatkal et al., 2010;
Jung and Joo, 2013). Namun selama proses penyimpanan, terjadi interaksi kompleks dengan matriks (Jakobek, 2015) sehingga $\mathrm{pH}$ dapat berubah dan cenderung naik. Pada penelitian ini, pada hari ke-6, pH sosis yang diberi ekstrak meningkat dan kemudian stabil hingga hari ke-12.

Nilai $a_{w}$ sosis sangat berkaitan dengan stabilitas masa simpan suatu produk. Hasil penelitian sebagaimana tampil pada Tabel 5 menunjukkan semakin lama waktu penyimpanan bersuhu dingin, nilai $a_{w}$ sosis cenderung menurun kecuali pada sosis EDS+nitrit dari hari ke-0 ke hari ke-3, yang meningkat tetapi kemudian menurun pada hari berikutnya. Hasil ini berbeda dengan penelitian lain yang menunjukkan nilai $\mathrm{a}_{\mathrm{w}}$ tidak berubah dengan waktu simpan dingin (Riel et al., 2017). Formula sosis tidak berpengaruh pada nilai $a_{w}$ kecuali pada penambahan EDS+nitrit pada hari ke-0. Rendahnya nilai $a_{w}$ pada sosis yang diberi EDS+nitrit diduga karena adanya penambahan ekstrak dan nitrit dalam menurunkan keberadaan air bebas pada sosis. Kisaran nilai $a_{w}$ sosis penelitian ini adalah 0,84-0,90 yang masih memungkinkan tumbuhnya bakteri pada sosis. Namun demikian $a_{w}$ sosis penelitian ini masih lebih rendah dari hasil-hasil penelitian sejenis sebelumnya (Riel et al., 2017).

Persentase kadar air sosis menunjukkan adanya penurunan dari hari ke-0 hingga hari ke-6 $(P<0,05)$. Setelah itu, kadar air cenderung tidak berubah hingga hari ke-12 (Tabel 5). Laju penurunan kadar air dari hari ke-0 hingga ke-12 adalah 2,2, 1,9, 2,4, dan 2,7\% per minggu, masing-masing untuk sosis kontrol, EDS, nitrit, dan EDS+nitrit. Menurunnya kadar air selama penyimpanan dingin sosis karena uap air dari permukaan sosis bermigrasi sebagai akibat dari perbedaan tekanan uap air dengan udara dingin di

Tabel 4. Nilai $\mathrm{pH}$ sosis selama penyimpanan dingin

\begin{tabular}{lcccccc}
\hline Sosis & Hari ke- 0 & Hari ke-3 & Hari ke-6 & Hari ke-9 & Hari ke-12 & Rata-rata \\
\hline Kontrol & $6,00 \pm 0,09$ & $5,99 \pm 0,02$ & $6,08 \pm 0,04$ & $6,05 \pm 0,01$ & $6,05 \pm 0,03$ & $6,03 \pm 0,053^{\mathrm{a}}$ \\
EDS & $5,82 \pm 0,07$ & $5,90 \pm 0,08$ & $5,94 \pm 0,08$ & $5,93 \pm 0,03$ & $5,99 \pm 0,08$ & $5,91 \pm 0,083^{\mathrm{b}}$ \\
Nitrit & $5,95 \pm 0,05$ & $6,00 \pm 0,06$ & $6,06 \pm 0,02$ & $5,99 \pm 0,06$ & $6,03 \pm 0,01$ & $6,01 \pm 0,054^{\mathrm{a}}$ \\
EDS+nitrit & $5,84 \pm 0,05$ & $5,87 \pm 0,02$ & $5,90 \pm 0,02$ & $5,95 \pm 0,05$ & $5,93 \pm 0,02$ & $5,90 \pm 0,052^{\mathrm{b}}$ \\
Rataan & $5,90 \pm 0,094^{\mathrm{b}}$ & $5,94 \pm 0,072^{\text {ab }}$ & $6,00 \pm 0,085^{\mathrm{a}}$ & $5,98 \pm 0,057^{\mathrm{a}}$ & $6,00 \pm 0,057^{\mathrm{a}}$ & \\
\hline
\end{tabular}

Keterangan: superskrip yang berbeda pada baris dan kolom yang sama menunjukkan berbeda nyata $(P<0,05)$

Tabel 5. Nilai $a_{w}$, kadar air, dan daya mengikat air sosis selama penyimpanan dingin

\begin{tabular}{cllllll}
\hline Variabel & Sosis & Hari ke -0 & Hari ke-3 & Hari ke- 6 & Hari ke-9 & Hari ke-12 \\
\hline $\mathrm{a}_{\mathrm{w}}$ & Kontrol & $0,90 \pm 0,018^{\mathrm{a}}$ & $0,88 \pm 0,005^{\text {bcd }}$ & $0,87 \pm 0,008^{\text {bcd }}$ & $0,87 \pm 0,014^{\text {cde }}$ & $0,86 \pm 0,006^{\text {cde }}$ \\
& EDS & $0,89 \pm 0,006^{\text {ab }}$ & $0,87 \pm 0,009^{\text {bcd }}$ & $0,87 \pm 0,002^{\text {cd }}$ & $0,86 \pm 0,007^{\text {cde }}$ & $0,85 \pm 0,006^{\text {cde }}$ \\
& Nitrit & $0,88 \pm 0,007^{\text {abc }}$ & $0,87 \pm 0,007^{\text {bcd }}$ & $0,87 \pm 0,001^{\text {bcd }}$ & $0,86 \pm 0,004^{\text {cd }}$ & $0,86 \pm 0,007^{\text {cde }}$ \\
& EDS+nitrit & $0,84 \pm 0,012^{\text {e }}$ & $0,87 \pm 0,006^{\text {bcd }}$ & $0,87 \pm 0,004^{\text {cd }}$ & $0,86 \pm 0,002^{\text {cde }}$ & $0,86 \pm 0,004^{\text {cde }}$ \\
\hline Kadar air & Kontrol & $62,70 \pm 0,15^{\text {a }}$ & $60,72 \pm 0,08^{\text {bc }}$ & $59,59 \pm 0,08^{\text {cd }}$ & $57,99 \pm 1,27^{\text {fgh }}$ & $57,38 \pm 0,32^{\text {fgh }}$ \\
$(\%)$ & EDS & $61,88 \pm 0,59^{\text {b }}$ & $59,61 \pm 1,08^{\text {cd }}$ & $58,00 \pm 0,03^{\text {fgh }}$ & $57,74 \pm 0,04^{\text {fgh }}$ & $57,24 \pm 0,07^{\text {fgh }}$ \\
& Nitrit & $62,54 \pm 0,06^{\text {ab }}$ & $59,43 \pm 0,04^{\text {ab }}$ & $58,07 \pm 0,10^{\text {efgh }}$ & $57,50 \pm 0,57^{\text {fgh }}$ & $56,70 \pm 0,48^{\text {hi }}$ \\
& EDS+nitrit & $62,05 \pm 0,02^{\text {ab }}$ & $58,65 \pm 0,29^{\text {cde }}$ & $58,40 \pm 0,09^{\text {defg }}$ & $57,42 \pm 0,22^{\text {fgh }}$ & $55,54 \pm 0,10^{i}$ \\
\hline DMA & Kontrol & $24,66 \pm 1,07^{g}$ & $28,75 \pm 1,14^{\text {def }}$ & $30,08 \pm 1,18^{\text {bcde }}$ & $29,43 \pm 1,14^{\text {bcdef }}$ & $28,91 \pm 0,51^{\text {cdet }}$ \\
$(\%$ mg & EDS & $28,01 \pm 0,18^{\text {ef }}$ & $30,28 \pm 0,17^{\text {bcd }}$ & $30,22 \pm 0,80^{\text {bcde }}$ & $28,97 \pm 1,13^{\text {cdef }}$ & $27,67 \pm 0,05^{\dagger}$ \\
$\left.\mathrm{H}_{2} \mathrm{O}\right)$ & Nitrit & $29,09 \pm 0,23^{\text {cde }}$ & $32,72 \pm 0,22^{\text {a }}$ & $30,85 \pm 0,40^{\text {abcd }}$ & $30,51 \pm 0,78^{\text {abcd }}$ & $29,33 \pm 0,99^{\text {bcdef }}$ \\
& EDS+nitrit & $28,90 \pm 0,65^{\text {cdef }}$ & $31,07 \pm 0,17^{\text {abc }}$ & $31,36 \pm 0,46^{\text {ab }}$ & $30,53 \pm 0,29^{\text {abcd }}$ & $27,84 \pm 0,23^{\dagger}$ \\
\hline
\end{tabular}

Keterangan: superskrip yang berbeda pada baris dan kolom yang sama pada tiap-tiap variabel menunjukkan berbeda nyata $(\mathrm{P}<0,05)$ 
sekitarnya (El-Nashi et al., 2015). Pemberian EDS dan nitrit cenderung menurunkan persentase kadar air sosis. $\mathrm{Hal}$ ini terlihat pada hari ke-12 dimana sosis yang diberi EDS+nitrit memiliki kadar air paling rendah $(55,54 \pm 0,10 \%)$. Kadar air sosis penelitian ini menunjukkan masih dalam kategori Standar Nasional Indonesia dimana kadar air sosis maksimal adalah $67 \%$ (BSN, 2015).

Daya Mengikat Air (DMA) menunjukkan kemampuan daging dalam mengikat air baik air yang ditambahkan atau airnya sendiri. Nilai DMA sosis penelitian ini berkisar 24,66-32,72\% (Tabel 5). Terdapat kecenderungan yang unik karena persentase air yang terlepas cenderung meningkat pada hari ke-3 dan ke-6 kemudian menurun pada hari ke-9 dan ke-12 penyimpanan. Pada hari ke-0, sosis kontrol melepas air bebas paling rendah $(P<0,05)$. Hari ke-3, sosis yang diberi nitrit menunjukkan air yang terlepas paling tinggi dibandingkan kontrol. Secara umum, penambahan ekstrak menunjukkan air yang terlepas sama dengan penambahan nitrit. Semakin tinggi persentase air yang terlepas maka daya mengikat airnya semakin rendah.
Bagaimana pengaruh senyawa polifenol terhadap daya mengikat air, belum banyak diketahui. Kemungkinan keberadaan bahan-bahan non-metabolit sekunder pada ekstrak air menyebabkan DMA meningkat. Chirinos et al. (2007) dan Chen et al. (2016) menyebutkan bahwa ekstrak tubuhan dengan menggunakan pelarut air menghasilkan juga bahan-bahan organik seperti karbohidrat dan lain-lain. Namun, DMA sosis secara umum dipengaruhi oleh kondisi daging, fosfat, garam dan $\mathrm{pH}$ daging (Peng et al., 2009; Puolanne and Peltonen, 2013).

\section{Warna Sosis}

Hasil pengujian warna sosis penelitian ini disajikan pada Tabel 6 yang dinyatakan menurut sistem Hunter $L^{*} a^{*} b^{*}$. Intensitas kecerahan warna sosis $\left(L^{*}\right)$ menunjukkan adanya interaksi antara formula sosis dengan waktu penyimpanan $(P<0,05)$. Sosis kontrol dan EDS menunjukkan intensitas kecerahan warna selama penyimpanan tidak berbeda, sedangkan pada sosis nitrit dan EDS+nitrit mengalami perubahan yang signifikan pada hari ke-6. Terjadi perbedaan pola perubahan

Tabel 6. Warna sosis selama penyimpanan dingin

\begin{tabular}{llccc}
\hline Variabel & Sosis & Hari ke- 0 & Hari ke- 6 & Hari ke-12 \\
\hline $\mathrm{L}^{*}$ & Kontrol & $51,13 \pm 1,83^{\text {cd }}$ & $53,04 \pm 0,67^{\mathrm{bcd}}$ & $49,90 \pm 0,70^{\mathrm{cd}}$ \\
& EDS & $59,59 \pm 3,31^{\mathrm{a}}$ & $57,36 \pm 2,16^{\mathrm{ab}}$ & $55,48 \pm 1,15^{\mathrm{abc}}$ \\
& Nitrit & $47,94 \pm 1,80^{\mathrm{d}}$ & $60,31 \pm 4,93^{\mathrm{a}}$ & $52,32 \pm 2,55^{\mathrm{bcd}}$ \\
& EDS+nitrit & $59,83 \pm 0,72^{\mathrm{a}}$ & $50,42 \pm 0,42^{\mathrm{cd}}$ & $50,66 \pm 0,40^{\mathrm{cd}}$ \\
\hline $\mathrm{a}^{*}$ & Kontrol & $4,82 \pm 0,54^{\mathrm{bcdef}}$ & $5,94 \pm 0,46^{\mathrm{abc}}$ & $3,39 \pm 0,24^{\text {ef }}$ \\
& EDS & $4,45 \pm 0,84^{\text {cdef }}$ & $3,14 \pm 0,61^{\dagger}$ & $3,76 \pm 0,44^{\text {def }}$ \\
& Nitrit & $7,44 \pm 1,20^{\mathrm{a}}$ & $6,38 \pm 0,39^{\mathrm{ab}}$ & $4,38 \pm 0,32^{\text {cdef }}$ \\
& EDS+nitrit & $5,17 \pm 0,16^{\mathrm{bcde}}$ & $5,21 \pm 0,70^{\mathrm{bcd}}$ & $5,55 \pm 0,42^{\mathrm{bcd}}$ \\
\hline $\mathrm{b}^{*}$ & Kontrol & $4,91 \pm 0,07^{\mathrm{b}}$ & $5,17 \pm 1,24^{\mathrm{b}}$ & $3,96 \pm 0,32^{\mathrm{bc}}$ \\
& EDS & $4,74 \pm 1,16^{\mathrm{b}}$ & $2,88 \pm 0,09^{\mathrm{c}}$ & $5,43 \pm 0,22^{\mathrm{ab}}$ \\
& Nitrit & $7,19 \pm 0,71^{\mathrm{a}}$ & $5,25 \pm 0,10^{\mathrm{b}}$ & $4,53 \pm 0,45^{\mathrm{bc}}$ \\
& EDS+nitrit & $5,15 \pm 0,36^{\mathrm{b}}$ & $4,95 \pm 0,46^{\mathrm{b}}$ & $4,90 \pm 0,32^{\mathrm{b}}$ \\
\hline
\end{tabular}

Keterangan: superskrip yang berbeda pada baris dan kolom yang sama pada tiap-tiap variabel menunjukkan berbeda nyata $(P<0,05)$

Tabel 7. Total senyawa fenolat, penghambatan DPPH, kapasitas antioksidan, nilai TBARS, dan residu nitrit sosis selama penyimpanan dingin

\begin{tabular}{|c|c|c|c|c|c|c|}
\hline Variabel & Sosis & Hari ke-0 & Hari ke-3 & Hari ke-6 & Hari ke-9 & Hari ke-12 \\
\hline \multirow{4}{*}{$\begin{array}{l}\text { Total senyawa } \\
\text { fenolat (mg } \\
\text { EAG/100 g } \\
\text { BK) }\end{array}$} & Kontrol & $130,63 \pm 7,50^{\text {cde }}$ & $128,50 \pm 11,72^{\mathrm{de}}$ & $117,58 \pm 8,59^{g h i}$ & $114,73 \pm 3,41^{\text {hij }}$ & $112,33 \pm 6,64^{\mathrm{ijk}}$ \\
\hline & EDS & $167,23 \pm 2,65^{a}$ & $134,85 \pm 3,60^{\mathrm{C}}$ & $133,09 \pm 3,60^{\mathrm{cd}}$ & $131,55 \pm 2,57^{\mathrm{cd}}$ & $131,01 \pm 2,76^{\text {cde }}$ \\
\hline & Nitrit & $127,66 \pm 2,38^{\text {de }}$ & $121,53 \pm 2,41^{\mathrm{fg}}$ & $113,85 \pm 2,25^{\mathrm{ijk}}$ & $111,64 \pm 2,83^{\mathrm{jk}}$ & $108,84 \pm 3,30^{k}$ \\
\hline & EDS+nitrit & $143,60 \pm 6,84^{b}$ & $130,63 \pm 6,42^{\text {cde }}$ & $130,06 \pm 5,12^{\text {cde }}$ & $125,19 \pm 1,99^{\text {ef }}$ & $119,95 \pm 2,30^{\text {fgh }}$ \\
\hline \multirow{4}{*}{$\begin{array}{l}\text { Penghambatan } \\
\text { DPPH (\%) }\end{array}$} & Kontrol & $24,98 \pm 1,71^{\mathrm{h}}$ & $27,13 \pm 1,61^{\mathrm{etg}}$ & $29,23 \pm 1,92^{\mathrm{d}}$ & $28,79 \pm 1,72^{\mathrm{de}}$ & $28,45 \pm 1,71^{\text {def }}$ \\
\hline & EDS & $40,65 \pm 1,90^{c}$ & $42,21 \pm 2,50^{\mathrm{abc}}$ & $42,66 \pm 3,09^{a b}$ & $42,05 \pm 3,32^{b c}$ & $42,60 \pm 1,92^{a b}$ \\
\hline & Nitrit & $26,04 \pm 2,04^{g h}$ & $25,45 \pm 2,04^{g h}$ & $26,71 \pm 1,64^{\text {tgh }}$ & $29,41 \pm 1,91^{d}$ & $29,18 \pm 2,80^{d}$ \\
\hline & EDS+nitrit & $42,56 \pm 1,93^{a b}$ & $42,48 \pm 2,04^{\mathrm{ab}}$ & $43,95 \pm 1,85^{a}$ & $42,65 \pm 2,20^{a b}$ & $42,11 \pm 2,74^{b c}$ \\
\hline \multirow{4}{*}{$\begin{array}{l}\text { Kapasitas } \\
\text { antioksidan } \\
\text { (mg ekivalen } \\
\text { BHT/100 g BK) }\end{array}$} & Kontrol & $36,79 \pm 1,10^{g h}$ & $38,02 \pm 0,77^{\mathrm{tg}}$ & $39,87 \pm 1,01^{\dagger}$ & $37,77 \pm 0,43^{\mathrm{tg}}$ & $36,79 \pm 0,45^{g h}$ \\
\hline & EDS & $55,85 \pm 0,76^{c d}$ & $55,78 \pm 1,49^{c d}$ & $56,03 \pm 1,98^{\mathrm{cd}}$ & $54,55 \pm 2,01^{\text {de }}$ & $55,31 \pm 0,36^{c d}$ \\
\hline & Nitrit & $38,22 \pm 1,64^{\mathrm{fg}}$ & $34,47 \pm 0,95^{i}$ & $35,05 \pm 0,63^{\mathrm{hi}}$ & $38,16 \pm 0,72^{\mathrm{fg}}$ & $37,13 \pm 1,82^{g h}$ \\
\hline & EDS+nitrit & $62,27 \pm 0,56^{a}$ & $57,03 \pm 0,59^{b c}$ & $58,68 \pm 0,17^{b}$ & $55,61 \pm 0,51^{c d}$ & $52,56 \pm 1,19^{e}$ \\
\hline \multirow{4}{*}{$\begin{array}{l}\text { TBARS (mg } \\
\text { MDA/Kg BK) }\end{array}$} & Kontrol & $2,06 \pm 0,013^{a}$ & $1,82 \pm 0,109^{b}$ & $1,56 \pm 0,096^{c}$ & $1,44 \pm 0,061^{\text {cdet }}$ & $1,73 \pm 0,064^{b}$ \\
\hline & EDS & $1,39 \pm 0,005^{\text {defg }}$ & $1,33 \pm 0,008^{\text {efg }}$ & $1,27 \pm 0,013^{g}$ & $1,30 \pm 0,036^{\mathrm{tg}}$ & $1,29 \pm 0,008^{\mathrm{g}}$ \\
\hline & Nitrit & $1,49 \pm 0,049^{c d}$ & $1,45 \pm 0,058^{\text {cde }}$ & $1,34 \pm 0,038^{\text {efg }}$ & $1,32 \pm 0,029^{\text {efg }}$ & $1,44 \pm 0,026^{\text {cdef }}$ \\
\hline & EDS+nitrit & $2,03 \pm 0,048^{a}$ & $1,58 \pm 0,062^{c}$ & $1,39 \pm 0,015^{\operatorname{detg}}$ & $1,57 \pm 0,010^{C}$ & $1,56 \pm 0,008^{c}$ \\
\hline \multirow{4}{*}{$\begin{array}{l}\text { Residu nitrit } \\
\text { (mg/Kg BK) }\end{array}$} & Kontrol & td & td & $\mathrm{td}$ & $\mathrm{td}$ & td \\
\hline & EDS & td & td & td & td & td \\
\hline & Nitrit & td & td & td & td & td \\
\hline & EDS+nitrit & $\mathrm{td}$ & td & $\mathrm{td}$ & td & $\mathrm{td}$ \\
\hline
\end{tabular}

Keterangan: superskrip yang berbeda pada baris dan kolom yang sama pada tiap-tiap variable menunjukkan berbeda nyata $(\mathrm{P}<0,05)$, td $=$ tidak terdeteksi 
intensitas kecerahan warna sosis nitrit dengan EDS+nitrit, yaitu sosis nitrit cenderung meningkat intensitasnya sedangkan sosis EDS+nitrit cenderung menurun. Hal ini kemungkinan karena EDS dapat menurunkan intensitas kecerahan selama penyimpanan hingga 6 hari. Bila dilihat berdasarkan formula sosis maka terlihat bahwa sosis yang diberi EDS dan EDS+nitrit memiliki intensitas kecerahan yang lebih rendah hingga hari ke- 6 dan ke-12 tidak berbeda nyata antarformula sosis. Hal ini menunjukkan bahwa penambahan ekstrak daun senduduk hanya mempengaruhi perubahan kecerahan warna sosis pada awal penyimpanan. Hasil penelitian ini mendukung penelitian sebelumnya dimana sosis disimpan hingga 28 hari tidak menunjukkan adanya perbedaan kecerahan warna (Riel et al., 2017).

Intensitas warna kemerahan sosis dalam sistem hunter ditunjukkan pada Tabel 6. Secara umum tidak terjadi penurunan intensitas warna kemerahan pada sosis selama penyimpanan dingin hingga 12 hari kecuali sosis yang ditambahkan nitrit pada hari ke-6 dan ke-12. Penyimpanan dingin produk hingga 29 hari belum menyebabkan perubahan tingkat kemerahan sosis (Riel et al., 2017). Diskolorisasi terjadi bila penyimpanan lebih dari 30 hari, yang ditandai dengan menurunnya tingkat kemerahan (Kim et al., 2013; Lorenzo et al., 2014b; Fernandes et al., 2018). Artinya, penyimpanan dingin hingga 12 hari belum menunjukkan adanya pembentukan metmioglobin atau konversi total pigmen menjadi pigmen nitroso yang menyebabkan diskolorisasi (Fernandes et al., 2018). Sosis yang ditambahkan nitrit memiliki nilai $a^{*}$ yang paling tinggi. Hal ini karena nitrit dapat membangkitkan dan mempertahankan warna merah pada daging (Honikel, 2008) sebagai komponen utama dalam sosis penelitian ini. Warna merah pada sosis tersebut karena nitrit membentuk nitrosilmioglobin (NOMb) kompleks, yaitu reaksi antara NO dengan myoglobin dan bila medapatkan panas membentuk nitrosilhemokromagen (Parthasarathy and Bryan, 2014). Kecuali pada hari ke-6, sosis yang mendapat tambahan EDS dan EDS+nitrit memiliki intensitas warna kemerahan yang sama dengan lainnya. Hal ini menunjukkan bahwa ekstrak daun senduduk pada formula ini tidak menyebabkan perubahan warna sosis. Nilai $a^{*}$ sosis 3,2 - 4,6 dipersepsi warna abu-abu dan nilai 4,6 - 10,8 dipersepsi sebagai coklat (Lorenzo et al., 2014b). Artinya, sosis penelitian ini menunjukkan cenderung keabu-abuan dan kecoklatan. Tingkat kemerahan sosis dipengaruhi oleh beberapa faktor, yaitu temperatur akhir, atmosfer gas, lamanya waktu simpan, dan interaksi antara waktu simpan dengan atmosfer gas (De Santos et al., 2007).

Derajat warna kekuningan (nilai $b^{\star}$ ) sosis dalam sistem hunter ditunjukkan pada Tabel 6. Lamanya waktu simpan berpengaruh pada menurunnya derajat kekuningan sosis kecuali pada sosis kontrol dan EDS+nitrit. Pada penyimpanan 12 hari, sosis EDS menunjukkan adanya peningkatan derajat kekuningan. Sedangkan pada sosis nitrit penurunan derajat kekuningan terjadi dari hari ke-0 ke hari ke-6. Kecuali pada hari ke- 0 , semua sosis memiliki derajat kekuningan yang tidak jauh berbeda. Pada hari ke-0, sosis nitrit memiliki derajat kekuningan tertinggi $(P<0,05)$.

\section{Fenolat, Penghambatan DPPH, Kapasitas Antioksidan}

Total fenolat, penghambatan DPPH, dan kapasitas antioksidan sosis ditunjukkan pada Tabel 7. Pada setiap waktu penyimpanan, kandungan senyawa fenolat sosis EDS dan EDS+nitrit lebih tinggi dibandingkan dengan sosis lainnya. Semakin lama penyimpanan menyebabkan kandungan senyawa fenolat sosis semakin menurun. Sosis EDS mengandung senyawa fenolat yang lebih tinggi dari pada sosis EDS+nitrit $(P<0,05)$. Tingginya kandungan senyawa fenolat pada sosis EDS dan EDS+nitrit adalah karena kontribusi oleh ekstrak daun senduduk. Hal ini karena daun senduduk mengandung senyawa-senyawa fenolat (Susanti et al., 2008; Wong et al., 2012; Anggraini and Lewandowsky, 2015), sedangkan senyawa fenolat yang didapati pada sosis tanpa penambahan ekstrak adalah berasal dari bumbu-bumbu.

Tingginya kandungan senyawa fenolat pada sosis EDS dan EDS+nitrit berpengaruh terhadap penghambatan DPPH dan kapasitas antioksidan yang lebih tinggi $(P<0,05)$ dibandingkan dengan sosis kontrol dan nitrit (Tabel 7). Respon aktivitas antioksidan sosis menunjukkan adanya interaksi antara formula sosis dengan waktu penyimpanan $(P<0,05)$. Pola aktivitas antioksidan cenderung meningkat hingga hari ke-6 kemudian sedikit perubahan hingga hari ke-12 penyimpanan (Tabel 7). Aktivitas antioksidan pada sosis dicerminkan oleh nilai penghambatan DPPH dan kapasitas antioksidan. Peningkatan aktivitas antioksidan terkait dengan total fenolat dari EDS yang berfungsi sebagai antioksidan (Zakaria et al., 2011; Alnajar et al., 2012; Alwash et al., 2014).

\section{Nilai TBARS dan Residu Nitrit}

Nilai TBARS sosis menunjukkan kadar malondialdehida (MDA) sebagai hasil oksidasi lipida pada produk dan dinyatakan dalam $\mathrm{mg} \mathrm{MDA} / \mathrm{Kg} \mathrm{BK}$ sosis. Nilai TBARS mengalami perubahan dengan lamanya waktu penyimpanan (Tabel 7). TBARS sosis kontrol lebih tinggi $(\mathrm{P}<0,05)$ dibandingkan dengan formula EDS dan nitrit. Hal ini menunjukkan bahwa EDS dan nitrit dalam formula ini memiliki kemampuan yang sepadan untuk mencegah oksidasi. Nitrit, selain dikenal sebagai pembangkit warna merah, juga memiliki kemampuan sebagai antioksidan (De Maere et al., 2016) dengan membentuk senyawa nitrosomioglobin stabil sehingga menghambat ion besi untuk oksidasi (Riazi et al., 2016). Nilai TBARS semua sosis masih di bawah ambang batas ketengikan yang dapat dideteksi, yaitu 5 $\mathrm{mg} \mathrm{MDA} / \mathrm{kg}$ bahan (Insausti et al., 2001). Rendahnya nilai TBARS pada sosis EDS dan EDS+nitrit karena senyawa-senyawa fenolat pada EDS berperan sebagai antioksidan dengan mencegah peningkatan oksidasi (Zakaria et al., 2011; Alnajar et al., 2012; Alwash et al., 2014). Aktivitas antioksidan senyawa fenolat terutama karena memiliki sifat potensial redoks sehingga berperan penting dalam absorbsi dan menetralisasi radikal bebas, menghambat oksigen singlet, dan 
Tabel 8. Total mikroba (CFU/g) pada sosis selama penyimpanan dingin

\begin{tabular}{|c|c|c|c|c|c|c|}
\hline Variabel & Sosis & Hari ke-0 & Hari ke-3 & Hari ke-6 & Hari ke-9 & Hari ke-12 \\
\hline \multirow[t]{4}{*}{ Total Plate Count } & Kontrol & $\mathrm{td}$ & $\mathrm{td}$ & $4,0 \times 10^{1}$ & $4,3 \times 10^{1}$ & $4,1 \times 10^{2}$ \\
\hline & EDS & td & td & $<10^{1}$ & $1,7 \times 10^{1}$ & $5,0 \times 10^{1}$ \\
\hline & Nitrit & td & $\mathrm{td}$ & $<10^{1}$ & $4,3 \times 10^{1}$ & $1,7 \times 10^{2}$ \\
\hline & EDS+nitrit & td & $\mathrm{td}$ & $\mathrm{td}$ & $2,7 \times 10^{1}$ & $6,0 \times 10^{1}$ \\
\hline \multirow[t]{4}{*}{ S. aureus } & Kontrol & td & td & td & $1,3 \times 10^{1}$ & $5,3 \times 10^{1}$ \\
\hline & EDS & td & td & td & $<10^{1}$ & $4,0 \times 10^{1}$ \\
\hline & Nitrit & td & $\mathrm{td}$ & td & $<10^{1}$ & $4,3 \times 10^{1}$ \\
\hline & EDS+nitrit & td & $\mathrm{td}$ & $\mathrm{td}$ & $<10^{1}$ & $5,0 \times 10^{1}$ \\
\hline \multirow[t]{4}{*}{ Salmonella sp. } & Kontrol & td & $\mathrm{td}$ & $\mathrm{td}$ & $<10^{1}$ & $<10^{1}$ \\
\hline & EDS & td & $\mathrm{td}$ & $\mathrm{td}$ & $<10^{1}$ & $<10^{1}$ \\
\hline & Nitrit & td & $\mathrm{td}$ & $\mathrm{td}$ & $<10^{1}$ & $<10^{1}$ \\
\hline & EDS+nitrit & td & td & td & $\mathrm{td}$ & $\mathrm{td}$ \\
\hline \multirow[t]{4}{*}{ E. coli (cfu/g) } & Kontrol & td & td & $\mathrm{td}$ & td & $\mathrm{td}$ \\
\hline & EDS & td & td & $\mathrm{td}$ & $\mathrm{td}$ & td \\
\hline & Nitrit & td & td & $\mathrm{td}$ & $\mathrm{td}$ & $\mathrm{td}$ \\
\hline & EDS+nitrit & td & td & $\mathrm{td}$ & td & $\mathrm{td}$ \\
\hline
\end{tabular}

Keterangan: $\mathrm{td}=$ tidak terdeteksi

mendekomposisi peroksida (Kalem et al., 2017). Penggunaan ekstrak tumbuhan sebagai antioksidan pada sosis menunjukkan senyawa-senyawa fenolat ekstrak tumbuhan berperan menurunkan tingkat oksidasi sosis (Jin et al., 2015; Kalem et al., 2017; Zhang et al., 2017).

Kemampuan senyawa fenolat sebagai antioksidan karena mengandung gugus $\mathrm{OH}$ dan/atau $\mathrm{NH}_{2}$ pada strukturnya (Bendary et al., 2013). Mekanismenya adalah dengan cara transfer atom $\mathrm{H}$ dari gugus $\mathrm{OH}$ senyawa fenolat kepada rantai radikal peroksil. Selanjutnya, reaksi terjadi dengan resultante radikal peroksil (Bendary et al., 2013). Senyawa fenolat berperan mendonorkan hidrogen dan bereaksi dengan reactive oxygen dan reactive nitrogen spesies pada reaksi terminasi yang berperan memecah siklus pembentukan radikal baru. Selanjutnya radikal yang terbentuk dari senyawa fenolat memiliki stabilitas kimia yang lebih stabil dibanding radikal awal (Pereira et al., 2009).

Residu nitrit sosis pada semua pengamatan tidak terdeteksi (Tabel 7). Hal ini menunjukkan bahwa penambahan nitrit sebesar $0,0011 \%$ tidak memberikan residu pada produk. Tidak terdeteksinya residu nitrit pada sosis kemungkinan karena jumlah yang ditambahkan masih sangat kecil sehingga masih di bawah batas ambang deteksi alat dan metode. Selain itu, kemungkinan karena nitrit bereaksi dengan myoglobin dan adanya proses pemanasan terbentuk nitrosilhemokromagen. Menurut Honikel (2008) bahwa konsentrasi nitrit akan menurun hingga 65\% sejak ditambahkan hingga selesai proses pemanasan. Pada sosis EDS+nitrit, kemungkinan karena adanya proses reduksi oleh senyawa-senyawa fenolat. Beberapa hasil penelitian sebelumnya menyebutkan bahwa senyawasenyawa fenolat dapat mereduksi nitrit pada produk dendeng (Suryati et al., 2014) dan dry-cured bacon (Wang et al., 2015). Oleh karena itu, faktor yang menyebabkan tidak terdeteksinya residu nitrit pada penelitian ini cukup kompleks. Tidak terdeteksinya residu nitrit menunjukkan produk ini aman dari efek negatif nitrit. Biasanya residu nitrit yang diizinkan adalah maksimum 100 mg/Kg produk daging (Directive, 2006).

\section{Mikrobiologi Sosis}

Hasil penelitian ini menunjukkan bahwa penyimpanan hari ke-6 ditemui adanya koloni mikroba (Tabel 8). Koloni yang terbentuk dalam hitungan total plate count tertinggi adalah sosis kontrol, sedangkan sosis EDS dan nitrit terbentuk koloni kurang dari $10^{1}$ CFU/g sampel. Pada sosis EDS+nitrit tidak ditemui adanya koloni tumbuh hingga penyimpanan hari ke-12. Total plate count cenderung meningkat dengan lamanya masa simpan sosis. Namun demikian, sosis yang mendapat tambahan ekstrak tumbuh koloni mikroba satu log, yaitu $10^{1}$, lebih rendah dari pada sosis tanpa ekstrak, yaitu $10^{2}$.

Koloni $S$. aureus dijumpai pada penyimpanan hari ke-9 dan cenderung meningkat dengan lamanya waktu simpan sosis (Tabel 8). Pada hari ke-9, koloni yang terbentuk pada sosis kontrol (1,3 × 10 $\mathrm{CFU} / \mathrm{g}$ sampel) lebih tinggi dibandingkan dengan sosis-sosis lainnya yang mana kurang dari $10^{1} \mathrm{CFU} / g$ sampel. Pada penyimpanan hari ke-12, semua sosis ditumbuhi koloni mikroorganisme yang berkisar $10^{1} \mathrm{CFU} / \mathrm{g}$ sampel. Sosis juga ditumbuhi koloni Salmonella sp. pada hari ke-9 dan ke-12 dengan jumlah kurang dari $10^{1} \mathrm{cfu} / \mathrm{g}$ sampel, kecuali sosis EDS+nitrit yang tidak ditumbuhi koloni Salmonella sp. Sedangkan bakteri E. coli tidak ditemui pada semua sosis hingga penyimpanan hari ke-12 (Tabel 8).

Hasil penelitian ini menunjukkan bahwa EDS dan nitrit pada formula sosis memiliki kemampuan antibakteri yang sepadan. Kombinasi dari keduanya memberi efek pada lebih tahan dan lebih rendahnya total mikroba serta mampu menekan Salmonella hingga penyimpanan hari ke-12. Hasil ini menunjukkan bahwa ekstrak dan nitrit memiliki kemampuan antibakteri. De Maere et al. (2016) menyebutkan bahwa nitrit selain untuk membangkitkan dan mempertahankan warna merah produk curing, juga berperan sebagai antibakteri, sedangkan sifat antibakteri ekstrak karena senyawa fenolat pada EDS (Susanti et 
al., 2008; Wong et al., 2012; Anggraini and Lewandowsky, 2015) yang berperan sebagai antibakteri (Zakaria et al., 2011; Alnajar et al., 2012; Alwash et al., 2014). Namun demikian pemberian EDS pada penelitian ini hanya dapat menekan Salmonella hingga penyimpanan hari ke-6 dan mulai tumbuh koloni pada hari ke-9 yang menurut SNI harus negatif (BSN, 2015). Sedangkan berdasarkan total plate count, E.coli, dan $S$. aureus pada sosis dalam penelitian ini, sudah dinilai sesuai dengan $\mathrm{SNI}$ sosis.

\section{Kesimpulan}

Penambahan ekstrak daun senduduk sebesar $0,55 \%$ pada sosis menghasilkan sosis yang lebih mampu menahan proses oksidasi dan menunda pertumbuhan bakteri patogen pada sosis. Ekstrak daun senduduk dan nitrit dapat menurunkan susut masak, $\mathrm{pH}$ sosis, dan daya mengikat air. Esktrak dan kombinasinya dengan nitrit tidak mempengaruhi warna sosis. Penambahan ekstrak daun senduduk dapat meningkatkan kandungan senyawa fenolat sosis sehingga mampu menurunkan nilai TBARS sosis. Kombinasi antara ekstrak dan nitrit dinilai dapat menekan pertumbuhan bakteri hingga penyimpanan 12 hari.

\section{Ucapan Terima Kasih}

Penelitian ini disponsori oleh Kementerian Riset Teknologi dan Pendidikan Tinggi melalui program beasiswa BPPDN dan hibah penelitian disertasi dengan nomor kontrak 061/ADD/SP2H/LT/DRPM/VIII/2007. Ucapan terimakasih juga disampaikan kepada Fakultas Pertanian Universitas Bengkulu atas bantuan dana penelitian.

\section{Daftar Pustaka}

Al-Saeedi, A.H., Hossain, M.A. 2015. Total phenols, total flavonoids contents and free radical scavenging activity of seeds crude extracts of pigeon pea traditionally used in Oman for the treatment of several chronic diseases. Asian Pacific Journal of Tropical Disease 5(4): 316-321. DOI: 10.1016 IS2222-1808(14)60790-8

Alnajar, Z.A., Abdulla, M.A., Ali, H.M., Alshawsh, M.A., Hadi, A.H. 2012. Acute toxicity evaluation, antibacterial, antioxidant and immunomodulatory effects of Melastoma malabathricum. Molecules 17: 3547-3559. DOI:10.3390/molecules17033547.

Alwash, M., Ibrahim, N., Yaacob, W., Din, L. 2014. Antibacterial, antioxidant and cytotoxicity properties of traditionally used Melastoma malabathricum linn leaves. Addvance Journal of Food Science and Technology 6(1): 6-12.

Anggraeni, D.A., Widjanarko, S.B., Ningtyas, D.W. 2014. Proporsi tepung Porang (Amorphophallus muelleri Blume): tepung maizena terhadap karakteristik sosis ayam Jurnal Pangan dan Agroindustri 2(3): 214-223.

Anggraini, T., Lewandowsky, P. 2015. The exotic plants of Indonesia: Mahkota Dewa (Phaleria macrocarpa), Sikaduduak (Melastoma malabathricum Linn) and Mengkudu (Morinda citrifolia) as potent antioxidant sources. International Journal of Advcanve Science and Engineering Information Technology 5(2): 5962.

AOAC. 2005. Association of Official Agricultural Chemists. Official methods of analysis of AOAC International (18th ed.). AOAC, Maryland.

Arief, I.I., Suryati, T., Afiyah, D., Wardhani, D. 2014a. Physicochemical and organoleptic of beef sausages with teak leaf extract (Tectona grandis) addition as preservative and natural dye. International Food Research Journal 21(5):2033-2040.

Arief, I.I., Wulandari, Z., Aditia, E., Baihaqi, M. 2014b. Physicochemical and microbiological properties of fermented lamb sausages using probiotic Lactobacillus plantarum IIA-2C12 as starter culture. Procedia Environmental Science 20: 352-356. DOI: 10.1016/j.proenv.2014.03.044.

Balamurugan, K., Nishanthini, A., Mohan, V.R. 2013. Antiulcer activity of Melastoma malabathricum L. leaf extracts (Melastomataceae). International Journal of Advance Research 1(5): 49-52.

Balamurugan, K., Nishanthini, A., Mohan, V.R. 2014. Antidiabetic and antihyperlipidaemic activity of ethanol extract of Melastoma malabathricum Linn. leaf in alloxan induced diabetic rats. Asian Pacific Journal of Tropical Biomedicine 4: S442448. DOI:10.12980/APJTB.4.2014C122.

Bendary, E., Francis, R., Ali, H., Sarwat, M., El Hady, S. 2013. Antioxidant and structure-activity relationships (SARs) of some phenolic and anilines compounds. Annals of Agricultural Sciences 58(2): 173-181. DOI: 10.1016/ j.aoas.2013.07.002.

BSN. 2015. Standar Nasional Indonesia: Sosis Daging. Badan Standardisasi Nasional. BSN, Jakarta.

Carocho, M., Morales, P., Ferreira, I.C.F.R. 2015. Review: Natural food additives: Quo vadis? Trends Food Science and Technololgy 45(2): 284-295. DOI: 10.1016/j.tifs.2015.06.007.

Chaves-López, C., Serio, A., Mazzarrino, G., Martuscelli, M., Scarpone, E., Paparella, A. 2015. Control of household mycoflora in fermented sausages using phenolic fractions from olive mill wastewaters. International Journal of Food Microbiology 207: 49-56. DOI: 10.1016/ j.jjfoodmicro.2015.04.040.

Chen, Q., Fung, K.Y., Lau, Y.T., Ng, K.M., Lau, D.T. 2016. Relationship between maceration and extraction yield in the production of Chinese herbal medicine. Food Bioproducts Processing 98: 236-243. DOI: 10.1016/j.fbp.2016.02.005.

Chirinos, R., Rogez, H., Campos, D., Pedreschi, R., Larondelle, Y. 2007. Optimization of extraction conditions of antioxidant phenolic compounds from mashua (Tropaeolum tuberosum Ruíz \& Pavón) tubers. Separation and Purification 
Technololgy, 55:217-225. DOI:10.1016/ j.seppur.2006.12.005.

De Maere, H., Fraeye, I., De Mey, E., Dewulf, L., Michiels, C., Paelinck, H., Chollet, S. 2016. Formation of naturally occurring pigments during the production of nitrite-free dry fermented sausages. Meat Science 114: 1-7. DOI: 10.1016/j.meatsci.2015.11.024.

De Santos, F., Rojas, M., Lockhorn, G., Brewer, M. 2007. Effect of carbon monoxide in modified atmosphere packaging, storage time and endpoint cooking temperature on the internal color of enhanced pork. Meat Science 77(4): 520-528. DOI: 10.1016/j.meatsci.2007.04.031.

Devatkal, S. K., Narsaiah, K., Borah, A. (2010). Antioxidant effect of extracts of kinnow rind, pomegranate rind and seed powders in cooked goat meat patties. Meat Science 85(1): 155-159. DOI: 10.1016/j.meatsci.2009.12.019.

Directive. 2006. Directive 2006/52/EC of the European Parliament and of the Council of 5 July 2006 amending Directive 95/2/EC on food additives other than colours and sweeteners and Directive 95/35/EC on sweeteners for use in foodstuffs. O.J. L204 of 26.7.2006.

Doughari, J., Manzara, S. 2008. In vitro antibacterial activity of crude leaf extracts of Mangifera indica Linn. African Journal of Microbiology Research 2(1): 067-072.

El-Nashi, H. B., Fattah, A. F. A. K. A., Rahman, N. R. A., El-Razik, M. A. 2015. Quality characteristics of beef sausage containing pomegranate peels during refrigerated storage. Annals of Agricultural Sciences, 60(2): 403-412. DOI: 10.1016/j.aoas.2015.10.002.

Falowo, A.B., Fayemi, P.O., Muchenje, V. 2014. Natural antioxidants against lipid-protein oxidative deterioration in meat and meat products: A review. Food Research International 64: 171181. DOI: 10.1016/j.foodres.2014.06.022.

Fernandes, R., Trindade, M., Lorenzo, J., de Melo, M. 2018. Assessment of the stability of sheep sausages with the addition of different concentrations of Origanum vulgare extract during storage. Meat Science 137: 244-257. DOI: 10.1016/j.meatsci.2017.11.018.

Gholib, D. 2009. Uji Daya Hambat Daun Senggani (Melastoma malabathricum L.) terhadap Trichophyton mentagrophytees dan Candida albicans. Berita Biologi. Balai Besar Penelitian Veteriner Bogor 9: 253-259.

Honikel, K.O. 2008. The use and control of nitrate and nitrite for the processing of meat products. Meat Sci., 78: 68-76. DOI:10.1016/j.meatsci. 2007.05.030.

Hung, Y., Verbeke, W., de Kok T.M. 2016. Stakeholder and consumer reactions towards innovative processed meat products: Insights from a qualitative study about nitrite reduction and phytochemical addition. Food Control 60: 690698. DOI:10.1016/j.foodcont.2015.09.002.
Ibrahim, H.M., Abou-Arab, A.A., Abu Salem, F.M. 2010. Addition of some natural plant extracts and their effects on lamb patties quality. Journal of Food Technology 8(3): 134-142. DOI: 10.3923/ jftech.2010.134.142.

Insausti, K., Beriain, M., Purroy, A., Alberti, P., Gorraiz, C., Alzueta, M. 2001. Shelf life of beef from local Spanish cattle breeds stored under modified atmosphere. Meat Science 57(3): 273-281. DOI: 10.1016/S0309-1740(00)00102-9.

Jakobek, L. 2015. Review: Interactions of polyphenols with carbohydrates, lipids and proteins. Food Chemistry 175: 556-567. DOI: 10.1016/ j.foodchem.2014.12.013.

Jin, S.-K., Ha, S.-R., Hur, S.-J., Choi, J.-S. 2015. Effect of various herbal medicine extracts on the physico-chemical properties of emulsion-type pork sausage. Journal of Food and Nutrition Research 3(5) 290-296. DOI:10.12691/jfnr-3-51.

Jung, E., Joo, N. 2013. Roselle (Hibiscus sabdariffa L.) and soybean oil effects on quality characteristics of pork patties studied by response surface methodology. Meat Science 94(3): 391-401. DOI: 10.1016/j.meatsci.2013.02.008.

Kalem, I.K., Bhat, Z.F., Kumar, S., Desai, A. 2017. Terminalia arjuna: A novel natural preservative for improved lipid oxidative stability and storage quality of muscle foods. Food Science and Human Wellness 6(4): 167-175. DOI: 10.1016 j.fshw.2017.08.001.

Karakaya, M., Bayrak, E., Ulusoy, K. 2011. Use of natural antioxidants in meat and meat products. Journal of Food Science and Engineering 1(1): 1-10.

Karre, L., Lopez, K., Getty, K.J. 2013. Natural antioxidants in meat and poultry products. Meat Science 94(2): 220-227. DOI: 10.1016/ j.meatsci.2013.01.007.

Kim, S.-J., Cho, A.R., Han, J. 2013. Antioxidant and antimicrobial activities of leafy green vegetable extracts and their applications to meat product preservation. Food Control 29(1): 112-120. DOI: 10.1016/j.foodcont.2012.05.060.

Lee, M., Han, D., Jeong, J., Choi, J., Choi, Y., Kim, H., Paik, H.-D., Kim, C. 2008. Effect of kimchi powder level and drying methods on quality characteristics of breakfast sausage. Meat Science 80(3): 708-714. DOI: 10.1016/ j.meatsci.2008.03.010.

Lorenzo, J.M., Gómez, M., Fonseca, S. 2014a. Effect of commercial starter cultures on physicochemical characteristics, microbial counts and free fatty acid composition of dry-cured foal sausage. Food Control 46: 382-389. DOI: 10.1016/j.foodcont.2014.05.025.

Lorenzo, J.M., Sineiro, J., Amado, I.R., Franco, D. 2014b. Influence of natural extracts on the shelf life of modified atmosphere-packaged pork patties. Meat Science 96: 526-534. DOI: 10.1016/j.meatsci.2013.08.007. 
Mahmoudi, S., Khali, M., Benkhaled, A., Benamirouche, K., Baiti, I. 2016. Phenolic and flavonoid contents, antioxidant and antimicrobial activities of leaf extracts from ten Algerian Ficus carica L. varieties. Asian Pacific Journal of Tropical Biomedicine 6(3): 239-245. DOI:10.1016/j.apjtb. 2015.12.010.

Mamat, S.S., Kamarolzaman, M.F.F., Yahya, F., Mahmood, N.D., Shahril, M.S., Jakius, K.F., Mohtarrudin, N., Ching, S.M., Susanti, D., Taher, M. 2013. Methanol extract of Melastoma malabathricum leaves exerted antioxidant and liver protective activity in rats. BMC Complementary and Alternative Medicine 13: 326. DOI: 10.1186/1472-6882-13-326.

Mariem, C., Sameh, M., Nadhem, S., Soumaya, Z., Najiba, Z., Raoudha, E.G. 2014. Antioxidant and antimicrobial properties of the extracts from Nitraria retusa fruits and their applications to meat product preservation. Industrial Crops and Products 55: 295-303. DOI: 10.1016/j.indcrop. 2014.01.036.

Oliveira, T.L.C.d., Junior, B.R.d.C.L., Ramos, A.L.S., Ramos, E.M., Piccoli, R.H., Cristianini, M. 2015. Phenolic carvacrol as a natural additive to improve the preservative effects of high pressure processing of low-sodium sliced vacuum-packed turkey breast ham. LWT - Food Science and Technology 64(2): 1297-1308. DOI:10.1016/j.Iwt.2015.06.011.

Parthasarathy, D., Bryan, N., 2014. Curing/Physiology of Nitric Oxide. In: Devine, C. (Ed.), Encyclopedia of Meat Sciences. Academic Press, Oxford, pp. 436-441.

Peng, W., Xu, X.-L., Zhou, G.-H. 2009. Effects of meat and phosphate level on water-holding capacity and texture of emulsion-type sausage during storage. Agricultural Sciences in China 8(12): 1475-1481. DOI: 10.1016/S1671-2927(08) 60361-2.

Pereira, D.M., Valentão, P., Pereira, J.A., Andrade, P.B. 2009. Phenolics: From chemistry to biology. Molecules, 14(6): 2202-2211. DOI:10.3390/ molecules 14062202 .

Puolanne, E., Peltonen, J. 2013. The effects of high salt and low $\mathrm{pH}$ on the water-holding of meat. Meat Science 93(2): 167-170. DOI: 10.1016/j.meatsci. 2012.08.015.

Radha-Krishnan, K., Babuskin, S., Azhagu Saravana Babu, P., Sasikala, M., Sabina, K., Archana, G., Sivarajan, M., Sukumar, M. 2014. Antimicrobial and antioxidant effects of spice extracts on the shelf life extension of raw chicken meat. International Journal of Food Microbiololgy 171: 32-40. DOI: 10.1016/j.ijfoodmicro.2013.11.011.

Riazi, F., Zeynali, F., Hoseini, E., Behmadi, H., Savadkoohi, S. 2016. Oxidation phenomena and color properties of grape pomace on nitritereduced meat emulsion systems. Meat science 121: 350-358. DOI: 10.1016/j.meatsci. 2016.07.008.
Riel, G., Boulaaba, A., Popp, J., Klein, G. 2017. Effects of parsley extract powder as an alternative for the direct addition of sodium nitrite in the production of mortadella-type sausages-Impact on microbiological, physicochemical and sensory aspects. Meat Science 131: 166-175. DOI: 10.1016/j.meatsci.2017.05.007.

Roslen, N.A., Alewi, N.A., Ahamada, H., Rasad, M.S. 2014. Cytotoxicity screening of Melastoma malabathricum extracts on human breast cancer cell lines in vitro. Asian Pacific Journal of Tropical Biomedice 4(7): 545-548. DOI: 10.12980/APJTB.4.2014C658.

Suharyanto, Mega, O., Badarina, I., 2015. Skim milk powder substitution with soymilk powder could improve physical properties of beef surimi-based sausage. Proceeding of The Third International Seminar on Animal Industry. Faculty of Animal Science, Bogor Agricultural University, Bogor, pp. 317-320.

Sukisman , Purnomo, H., Rosyidi, D., Radiati, L.E. 2014. Quality properties, antioxidant capacity and total phenolic content of traditional deep fried shredded meat (abon) of Palu, Central Sulawesi. American Journal of Food Technology 9: 80-88. DOI: 10.3923/ajft.2014.80.88.

Sultana, T., Rana, J., Chakraborty, S.R., Das, K.K., Rahman, T., Noor, R. 2014. Microbiological analysis of common preservatives used in food items and demonstration of their in vitro antibacterial activity. Asian Pacific Journal of Tropical Disease 4(6): 452-456. DOI:10.1016/ S2222-1808(14)60605-8.

Suryati, T., Astawan, M., Lioe, H.N., Wresdiyati, T., Usmiati, S. 2014. Nitrite residue andmalonaldehyde reduction in dendeng Indonesian dried meat - influenced by spices, curing methods and precooking preparation. Meat Science 96(3): 1403-1408. DOI: 10.1016/j.meatsci.2013.11.023.

Susanti, D., Sirat, H.M., Ahmad, F., Ali, R.M., Aimi, N., Kitajima, M. 2007. Antioxidant and cytotoxic flavonoids from the flowers of Melastoma malabathricum L. Food Chem., 103(3): 710-716. DOI:10.1016/j.foodchem.2006.09.011.

Susanti, D., Sirat, H.M., Ahmad, F., Ali, R.M. 2008. Bioactive constituents from the leaves of Melastoma malabathricum L. Jurnal IImiah Farmasi, 5: 1-8.

Tiwari, R.P., Hoondal, G.S., Tewari, R. 2009. Laboratory Techniques in Microbiology and Biotechnology. Abhishek, Chandigarh.

Turgut, S.S., Soyer, A., Işıkçı, F. 2016. Effect of pomegranate peel extract on lipid and protein oxidation in beef meatballs during refrigerated storage. Meat Science 116: 126-132. DOI: 10.1016/j.meatsci.2016.02.011.

Wang, Y., Li, F., Zhuang, H., Chen, X., Li, L., Qiao, W., Zhang, J. 2015. Effects of plant polyphenols and a-tocopherol on lipid oxidation, residual nitrites, biogenic amines, and $\mathrm{N}$-nitrosamines formation 
during ripening and storage of dry-cured bacon. LWT-Food Science and Technology, 60(1): 199206.

Wong, K.-C., Hag Ali, D.M., Boey, P.-L. 2012. Chemical constituents and antibacterial activity of Melastoma malabathricum L. Natural Products Research 26(7): 609-618. DOI: 10.1080/ 14786419.2010 .538395$.

Zakaria, Z.A., Rofiee, M.S., Mohamed, A.M., Teh, L.K., Salleh, M.Z. 2011. In vitro antiproliferative and antioxidant activities and total phenolic contents of the extracts of Melastoma malabathricum leaves. Journal of Acupuncture \& Meridian Studies 4(4): 248-256. DOI:10.1016/ j.jams.2011.09.016

Zhang, Q.Q., Jiang, M., Rui, X., Li, W., Chen, X.H., Dong, M.S. 2017. Effect of rose polyphenols on oxidation, biogenic amines and microbial diversity in naturally dry fermented sausages. Food Control 78: 324-330. DOI: 10.1016/ j.foodcont.2017.02.054. 